\title{
Pemanfaatan daun sereh (Cymbopogon citratus) dan lidah mertua (Sansevieria trifasciata) sebagai kisi difraksi sederhana berbantuan tracker
}

\author{
Azizah Mutiarani \\ Pendidikan Fisika, Universitas Negeri Semarang, Indonesia \\ Surat-e: AMutiarani@students.unnes.ac.id \\ Durrotun Nafisah \\ Pendidikan Fisika, Universitas Negeri Semarang, Indonesia \\ Surat-e: dnafisah857@gmail.com

\section{Putut Marwoto} \\ Pendidikan Fisika, Universitas Negeri Semarang, Indonesia \\ Surat-e:pmarwoto@mail.unnes.ac.id

\section{Bambang Subali} \\ Pendidikan Fisika, Universitas Negeri Semarang, Indonesia \\ Surat-e: bambangfisika@mail.unnes.ac.id \\ Fianti \\ Pendidikan Fisika, Universitas Negeri Semarang, Indonesia \\ Surat-e: fianti@mail.unnes.ac.id

\section{Luqman Hakim} \\ Pendidikan Fisika, Universitas Negeri Semarang, Indonesia \\ Surat-e: luqmanhakim1922@students.unnes.ac.id
}

\begin{abstract}
Abstrak. Gelombang cahaya yang mengalami pelenturan ketika melewati sebuah celah sempit disebut dengan fenomena difraksi. Fenomena difraksi dapat dilihat dengan melakukan eksperimen sederhana menggunakan bahan alam. Penelitian ini menggunakan kisi berbahan daun sereh (Cymbopogon citratus) dan tanaman lidah mertua (Sansevieria trifasciata) dengan menggunakan laser merah $(\lambda=632,8 \mathrm{~nm})$ dengan beberapa variasi jarak kisi terhadap layar. Pola difraksi dianalisis menggunakan perangkat lunak Tracker. Hasil penelitian ini menunjukkan bahwa kisi difraksi menggunakan daun sereh dan lidah mertua menunjukkan fenomena difraksi cahaya sehingga dapat digunakan sebagai kisi difraksi sederhana berbahan alam dengan nilai $d=(34.20 \pm 7.86) \times 10^{-6} \mathrm{~m}$ dan $d=(62.50 \pm 13.60) \times 10^{-6} \mathrm{~m}$ pada kisi difraksi tanaman lidah mertua.
\end{abstract}

Kata kunci: sereh, lidah mertua, kisi difraksi, tracker.

\begin{abstract}
The light waves which flex when they pass through a narrow gap are called diffraction. The diffraction phenomenon can be seen by conducting simple experiments using natural materials. This study used a diffraction grating made from lemongrass leaves (Cymbopogon citratus) and sansevieria (Sansevieria trifasciata) using a red laser $(\lambda=632.8$ $\mathrm{nm})$ with several variations in the distance of the diffraction grating to the screen. The diffraction patterns were analyzed using Tracker software. The results of this study show that the diffraction grating using lemongrass leaves and sansevieria show the phenomenon of light diffraction so that it can be used as a simple diffraction grating made from natural ingredients with values $d=(34.20 \pm 7.86) \times 10^{-6} \mathrm{~m}$ of lemongrass leaves and $d=(62.50 \pm 13.60) \times 10^{-6} \mathrm{~m}$ for the diffraction grating of the sansevieria.
\end{abstract}

Keywords: lemongrass, sansevieria, diffraction grating, tracker 


\section{Pendahuluan}

Fenomena difraksi merupakan salah satu materi dalam pembelajaran fisika yang menunjukan peristiwa pelenturan gelombang cahaya melalui celah sempit. Gelombang cahaya yang melalui celah sempit akan menunjukan sebuah pola berupa pita terang dan gelap yang jatuh pada bidang horizontal [1]. Jarak antar pita terang dan gelap $(y)$ dipengaruhi oleh panjang gelombang $(\lambda)$, jarak celah dengan layar $(L)$, lebar celah $(\mathrm{d})$ serta $\mathrm{n}$ adalah pola gelap ke-n [2]. Hubungannya dapat dilihat pada persamaan (1).

$$
d \frac{y}{L}=n \lambda
$$

Untuk mendapatkan pola difraksi dapat menggunakan sebuah kisi difraksi. Kisi difraksi merupakan deretan garis-garis yang memiliki jarak yang sama antar garisnya [3]. Setiap celah pada kisi menghasilkan sebuah pola gelap terang akibat dari sinar yang terdifraksi kemudian saling berinterferensi. Intensitas pola difraksi yang dihasilkan oleh sebuah kisi dapat dilihat pada Gambar 1.

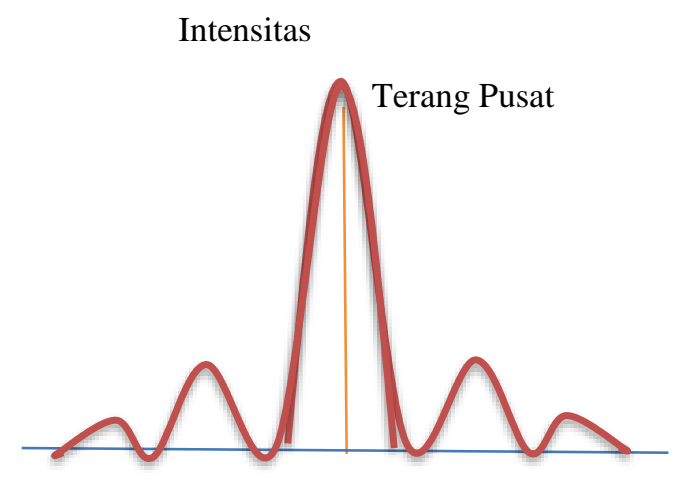

Gambar 1. Grafik Intensitas Pola Difraksi [4]

Pola difraksi dapat terjadi dengan menggunakan kisi dari bahan-bahan alam seperti pelepah pisang [5], kulit bawang [6] dan batang talas [7]. Hal tersebut terjadi karena adanya celah sempit yang terdapat pada bahan alam tersebut. Selain bahan alam, terdapat bahan non alam seperti plastik [8] dan keping DVD [9] yang dapat digunakan sebagai kisi difraksi sederhana. Pemanfaatan bahan alam sebagai kisi difraksi, dapat menunjukan fenomena difraksi yang nyata dengan menggunakan alat dan bahan yang sederhana, mudah dan tidak memerlukan biaya yang mahal [5]. Sehingga dapat digunakan untuk kegiatan pembelajaran yang bermakna, interaktif dan memotivasi siswa untuk membangun pengetahuannya secara mandiri [10]. Selain kegiatan pembelajaran, kisi difraksi dapat dimanfaatkan untuk menghitung diameter rambut serta dapat membedakan apel organik dan non-organik [11].

Daun sereh (Cymbopogon citratus) seperti pada Gambar 2a. merupakan salah satu rerumputan yang berlimpah serta memiliki banyak kandungan serat sehingga membentuk celah [12]. Selain daun sereh, tanaman lidah mertua (Sansevieria trifasciata) dapat dilihat pada Gambar 2b. juga memiliki serat alam [13]. Serat pada tanaman lidah mertua memiliki karakter yang tidak mudah putus sehingga serat lidah mertua biasa dimanfaatkan untuk bahan tekstil [14]. Penelitian ini bertujuan untuk menunjukan fenomena difraksi dengan memanfaatkan kandungan serat daun sereh (Cymbopogon citratus) dan serat tanaman lidah mertua (Sansevieria trifasciata) sebagai kisi difraksi sederhana dan mudah diperoleh berbantuan perangkat lunak Tracker untuk mendapatkan analisis gambar pada percobaan difraksi sederhana. 


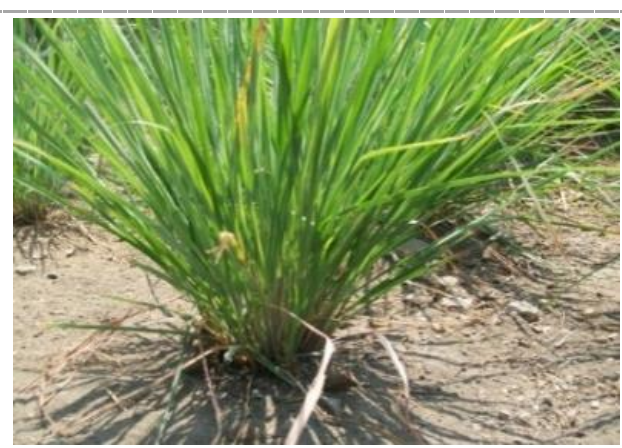

(a)

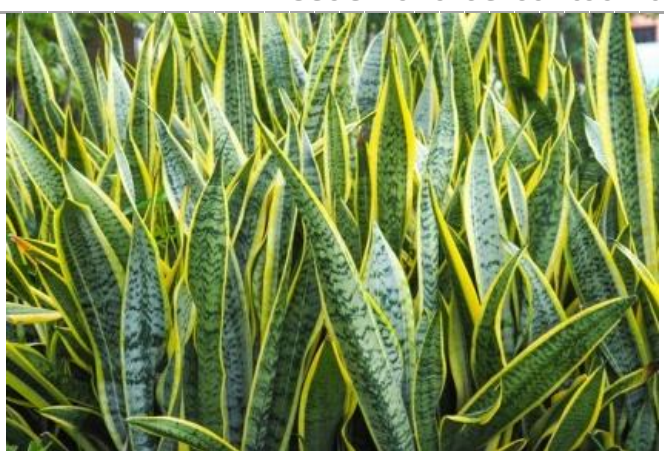

(b)

Gambar 2. (a) Tanaman Daun Sereh (Cymbopogon citratus) (b) Tanaman Lidah Mertua (Sansevieria trifasciata)

\section{Metode Penelitian}

Metode yang digunakan adalah metode eksperimen. Kisi difraksi yang digunakan yaitu daun sereh (Cymbopogon citratus) dan lidah mertua (Sansevieria trifasciata) yang dibuat dengan cara mengupas sereh dan lidah mertua hingga seratnya terlihat seperti pada Gambar 3.

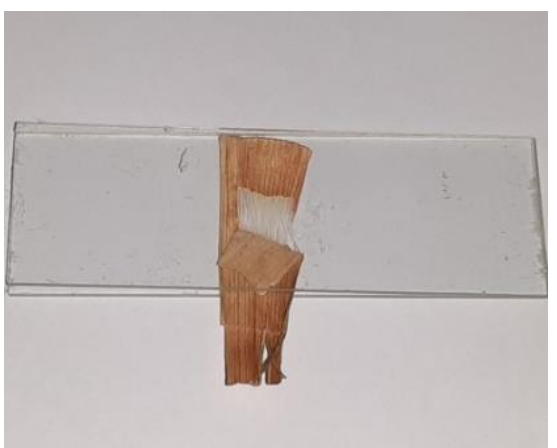

(a)

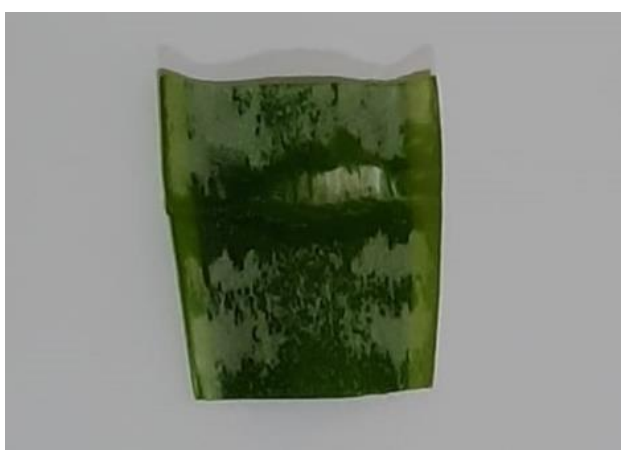

(b)

Gambar 3. (a) Preparat Daun Sereh (b) Perparat Lidah Mertua

Alat dan bahan yang digunakan yaitu, laser merah dengan panjang gelombang $632 \mathrm{~nm}$, kertas HVS A4 sebagai layar, dudukan kisi, lintasan rel sebagai acuan jarak, kisi daun sereh dan daun lidah mertua, catu daya sebagai sumber listrik, kamera serta aplikasi Tracker untuk menganalisis pola difraksi [15]. Secara keseluruhan rangkaian alat dapat dilihat pada Gambar 4.

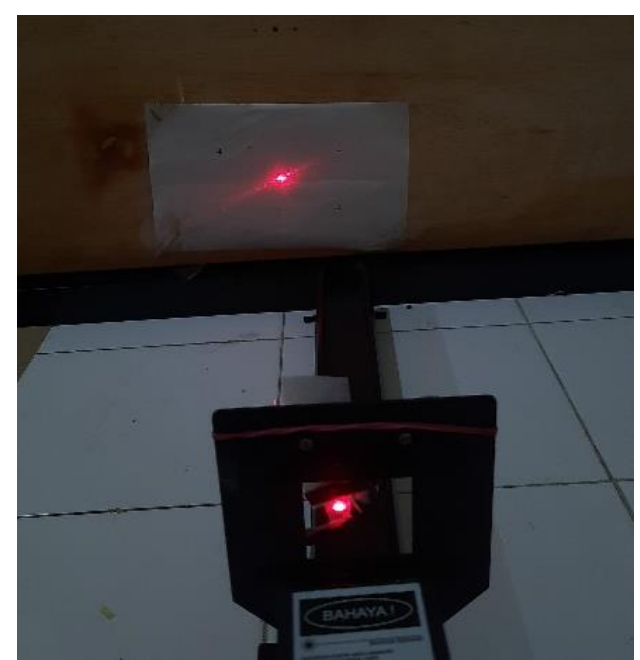

Gambar 4. Rangkaian alat 
Gambar 4. menunjukkan dudukan kisi difraksi diatas lintasan rel yang dapat digeser maju dan mundur, kemudian terdapat laser tepat dibelakang dudukan kisi difraksi. Di depan rel terdapat layar yang dapat diatur jaraknya untuk menujukkan pola difraksi yang terbentuk. Setelah pola difraksi terlihat pada layar, hasil pola gelap terangnya ditangkap menggunakan kamera yang kemudian akan di proses olah data menggunakan Tracker. Untuk memperoleh informasi jarak terang pusat dan gelap serta grafik intensitas pola difraksi pada Tracker menggunakan coordinate axes untuk menentukan garis koordinat dan tarik garis (Line Profile) pada menu Track.

\section{Hasil Penelitian dan Pembahasan}

Hasil penelitian ini menunjukkan bahwa terdapat pola difraksi dengan menggunakan kisi daun sereh dan daun lidah mertua yang ditunjukkan oleh Gambar 5.

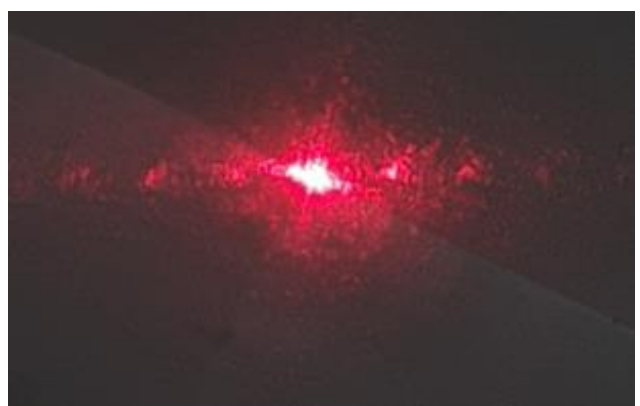

(a)

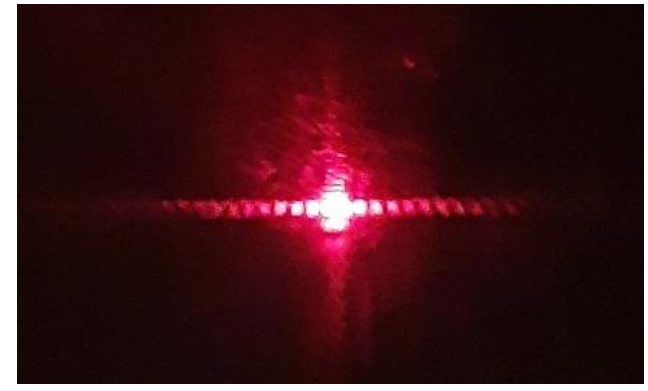

(b)

Gambar 5. (a) Pola difraksi kisi sereh (b) Pola difraksi kisi lidah mertua

Cahaya yang disinarkan tegak lurus melalui kisi tersebut menghasilkan gelombang cahaya sekunder dimana panjang gelombang yang datang akan sama dengan panjang gelombang sekunder. Berdasarkan Gambar 5 . terlihat pola difraksi yang menunjukkan adanya daerah yang paling terang hingga daerah disampingnya intensitas cahaya mulai meredup. Cahaya yang paling terang di tengah pola adalah terang pusat. Pada bagian kanan dan kiri di antara pita terang terdapat daerah yang tidak ada cahaya yaitu pita gelap.

Setelah didapatkan gambar pola difraksi yang terbentuk, kemudian dilakukan analisis gambar menggunakan Tracker untuk mengetahui grafik dan jarak antara pita gelap dan terang (y). Hasil analisis pola difraksi dapat dilihat pada Gambar 6.

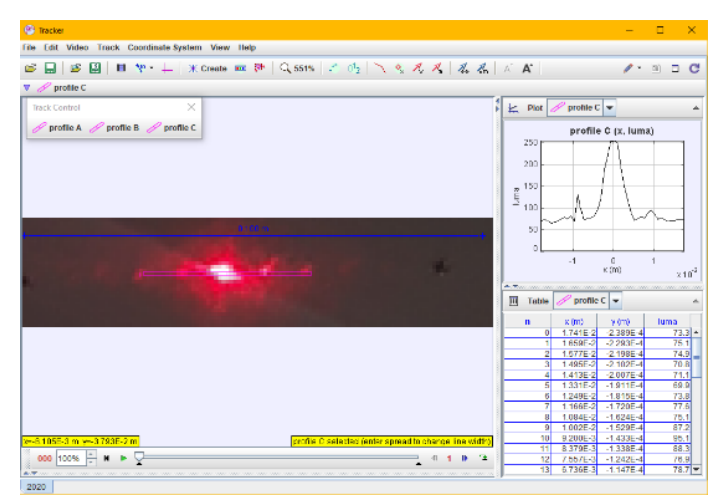

(a)

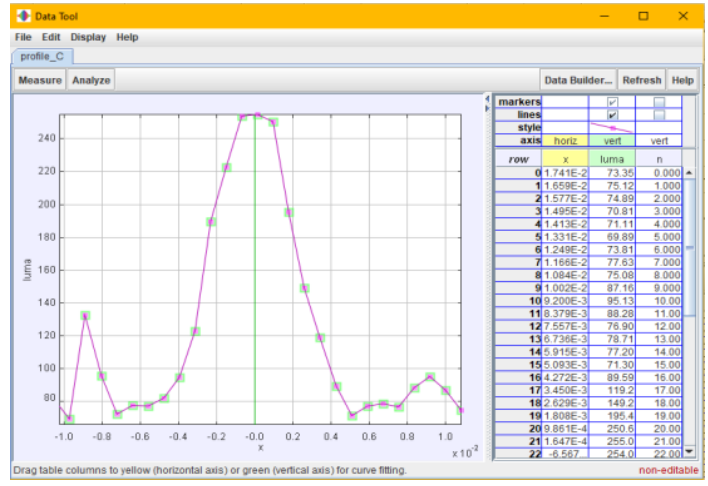

(b) 


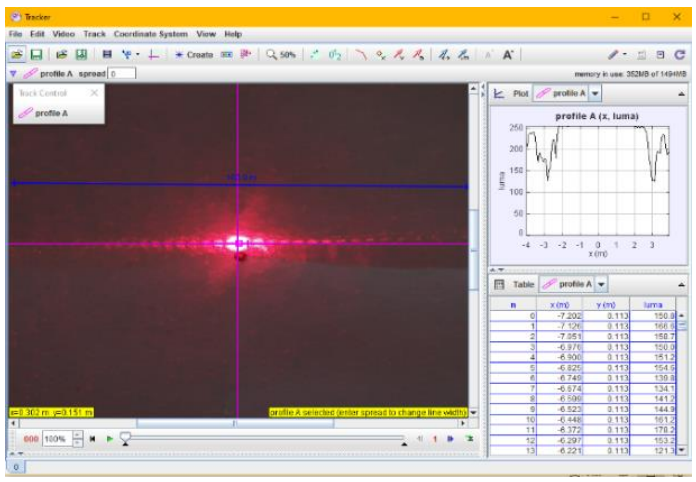

(c)

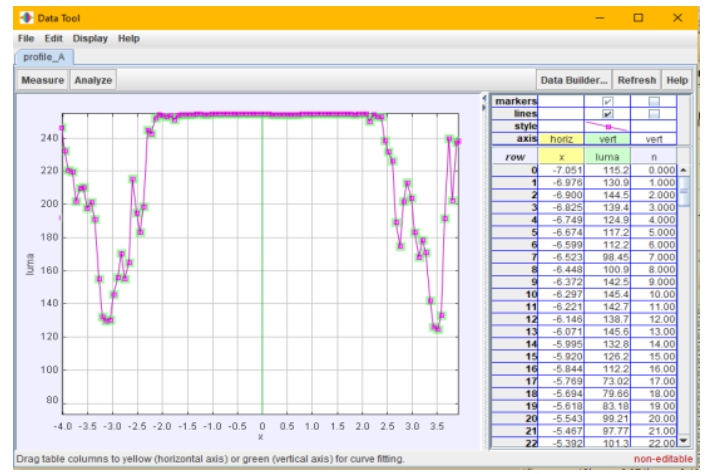

(d)

Gambar 6. (a) dan (b) Hasil analisis periodic pola difraksi daun sereh dengan menggunakan tracker, (d) dan (c) Hasil analisis periodik pola difraksi lidah mertua dengan menggunakan tracker.

Berdasarkan Gambar 6a. hasil analisis periodik Tracker dengan menggunakan kisi daun sereh menunjukkan pola gelap terang. Selain itu, pada Gambar 6b. didapatkan pola intensitas difraksi periodik yang sama dengan Gambar 1. Hal ini menunjukkan bahwa serat daun sereh dapat digunakan sebagai kisi difraksi.

Pada kisi difraksi lidah mertua terdapat pola gelap terang. Namun, pola yang terbentuk pada Gambar 6c. terlihat kurang jelas (blur) sehingga terkesan rapat pola gelap terangnya. Pada gambar 6d. menujukkan pola intensitas difraksi yang dihasilkan kisi lidah mertua tidak sama dengan Gambar 1. Hal tersebut terjadi karena lidah mertua yang digunakan sebagai sampel masih basah sehingga jarak antar serat tidak sama karena adanya kandungan air yang mengakibatkan gelombang cahaya menjadi tersebar [7]. Setelah menganalisa pola difraksi kedua kisi tersebut didapatkan jarak antar pita. Grafik hubungan jarak antar pita (y) dengan jarak kisi terhadap layar $(L)$ dapat dilihat pada Gambar 7.

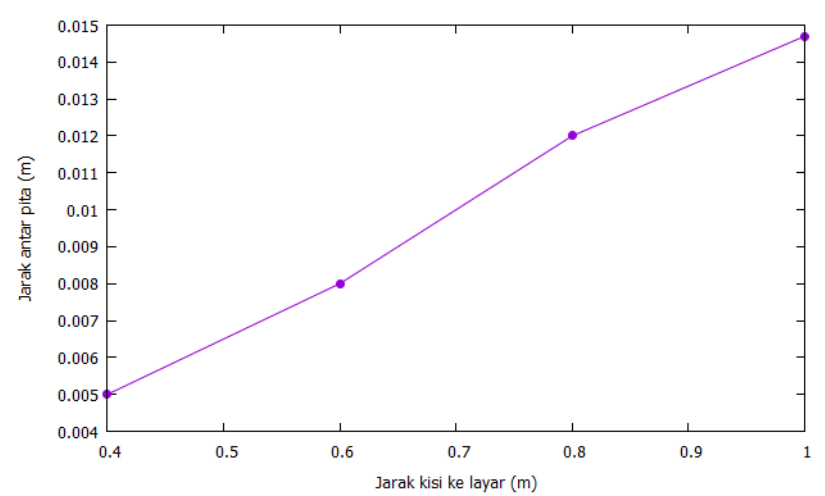

(a)

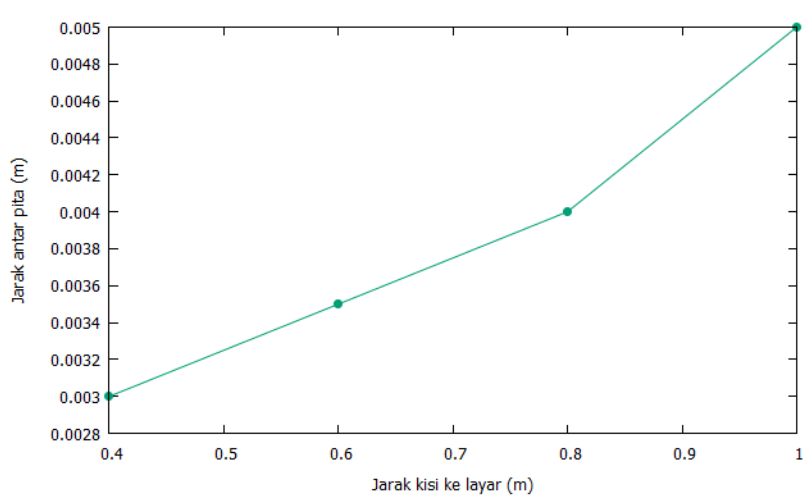

(b)

Gambar 7. (a) Grafik hubungan jarak antar pita ( $y$ ) dengan jarak kisi daun sereh terhadap layar $(L)$ (b) Grafik hubungan jarak antar pita $(y)$ dengan jarak kisi lidah mertua terhadap layar $(L)$

Berdasarkan kedua grafik diatas menunjukkan bahwa semakin besar jarak kisi terhadap layar $(L)$ maka jarak antar celah yang dihasilkan semakin besar atau berbanding lurus. Berdasarkan hasil analisis yang dilakukan dengan menggunakan ralat grafik diperoleh nilai $d=(34.20 \pm 7.86) \times 10^{-6} \mathrm{~m}$ pada kisi daun sereh dengan kesalahan relative sebesar $22 \%$ dan ketelitian $78 \%$. Pada hasil analisis ralat grafik kisi difraksi menggunakan lidah mertua didapatkan $d=(62.50 \pm 13.60) \times 10^{-6} \mathrm{~m}$ dengan kesalahan relative sebesar $21 \%$ dan ketelitian $79 \%$. 


\section{Kesimpulan}

Eksperimen kisi difraksi menggunakan daun sereh (Cymbopogon citratus) dan lidah mertua (Sansevieria trifasciata) berhasil menunjukkan pola gelap terang sesuai dengan teori difraksi cahaya sehingga kedua kisi tersebut dapat digunakan sebagai kisi difraksi sederhana untuk diaplikasikan pada pembelajaran.

\section{Ucapan Terimakasih}

Ucapan terimakasih kepada Prof. Dr. Putut Marwoto M.Si. dan Dr. Bambang Subali, M.Pd. selaku dosen pembimbing, kepada rekan saya Durrotun Nafisah, Luqman, Bu Upik dan Pak Wasi yang telah mengijinkan dan mempersiapkan alat-alat di lab serta membantu dalam proses penelitian hingga tuntas.

\section{Kepustakaan}

[1] N. R. Jetty, A. Suman, and R. B. Khaparde, "Novel cases of diffraction of light from a grating: Theory and experiment," Am. J. Phys., vol. 80, no. 11, pp. 972-979, 2012, doi: 10.1119/1.4737854.

[2] A. Nuraeni, N. N. Nurfa, P. A. Nisa, U. H. Azzahra, and E. Sujarwanto, "Penentuan Diameter Rambut Menggunakan Laser," J. Phys. Educ. Appl. Phys., vol. 1, no. 2, pp. 29-33, 2019.

[3] G. Lestari, "Pengukuran Panjang Gelombang Cahaya Laser Dioda Mengunakan Kisi Difraksi Refleksi dan Transmisi Laser He - Ne Laser Hijau Laser Merah,” Semirata 2013 FMIPA UNILA, pp. 167-171, 2013.

[4] R. a. Serway and J. W. Jewett, "Physics for Scientists and Engineers with Modern Physic, 7 ed," Brooks/cole, 2008.

[5] M. P. Aji, P. I. Karunawan, J. Chasanah, W A. Nursuhud, and P. A. S. Wiguna, "A simple diffraction experiment using banana stem as a natural grating," Phys. Educ., vol. 52, no. 2, pp. 1-6, 2017.

[6] J. R. Groff, "Estimating the Size of Onion Epidermal Cells from Diffraction Patterns," Phys. Teach., vol. 50, no. 7, pp. 420-423, 2012, doi: 10.1119/1.4752048.

[7] A. Prabawani and S. Wahyuni, "Kisi Difraksi dengan Menggunakan Batang Talas (Colocasia esculenta)," Unnes Phys. J., vol. 6, no. 1, pp. 74-77, 2017.

[8] M. P. Aji, A. Prabawani, I. Rahmawati, J. A. Rahmawati, A. Priyanto, and T. Darsono, "A diffraction grating from a plastic bag," Phys. Educ., vol. 54, no. 3, 2019, doi: 10.1088/1361-6552/ab0e4e.

[9] S. S. Khumaedi, "PERCOBAAN KISI DIFRAKSI DENGAN MENGGUNAKAN KEPING DVD DAN VCD," J. Pendidik. Fis. Indones., 2010, doi: 10.15294/jpfi.v6i1.1098.

[10] M. Y. Kholifudin, "Sinar Laser Mainan Sebagai Alternatif Sumbar cahaya Monokromatik Praktikum Kisi Difraksi Cahaya," J. Penelit. Pembelajaran Fis., vol. 8, no. 2, pp. 129-134, 2017, doi: 10.26877/jp2f.v8i2.1641.

[11] N. Jiang, W. Song, H. Wang, G. Guo, and Y. Liu, "Differentiation between organic and non-organic apples using diffraction grating and image processing - A cost-effective approach," Sensors (Switzerland), vol. 18, no. 6, pp. 1-14, 2018, doi: 10.3390/s18061667.

[12] A. N. M. A. Haque, R. Remadevi, and M. Naebe, "Lemongrass (Cymbopogon): a review on its structure, properties, applications and recent developments," Cellulose, vol. 25, no. 10, pp. 5455-5477, 2018, doi: 10.1007/s10570-018-1965-2.

[13] F. E. Yetti, "Pengaruh Presentase Massa Partikel Kayu dan Serat Lidah Mertua pada Core terhadap Sifat Fisis dan Mekanis Papan Partikel," J. Fis. Unand, vol. 8, no. 4, pp. 380-386, 2019.

[14] R. T. Anjani, B. N. Haq, and Y. F. Andriana, "Eksplorasi Teknik Tapestri dan Pewarnaan Serat Lidah Mertua untuk Bahan Alternatif Aksesoris Fesyen,” J. IKRA-ITH Hum., vol. 4, no. 3, pp. 219-228, 2020.

[15] M. Rodrigues, M. B. Marques, and P. Simeão Carvalho, "How to build a low cost spectrometer with Tracker for teaching light spectra," Phys. Educ., vol. 51, no. 1, 2016, doi: 10.1088/0031-9120/51/1/014002. 